\title{
CHEMICAL COMPOSITION AND ANTIMICROBIAL ACTIVITY OF THE ESSENTIAL OIL OF Hyptis pectinata (L.) POIT.
}

Patrícia O. Santos, Marcilene de J. C. Costa, José A. B. Alves, Paula F. C. Nascimento, Dângelly L. F. M. de Melo, Antônio M. Barbosa Jr. e Rita de C. Trindade*

Departamento de Morfologia, Centro de Ciências Básicas da Saúde, Universidade Federal de Sergipe, 49100-000 São Cristóvão

- SE, Brasil

Arie F. Blank

Departamento de Engenharia Agronômica, Universidade Federal de Sergipe, 49100-000 São Cristóvão - SE, Brasil

Maria F. Arrigoni-Blank

Núcleo de Ciências Biológicas, Campus Prof. Alberto Carvalho, Itabaiana - SE, Brasil

Péricles B. Alves

Departamento de Química, Universidade Federal de Sergipe, 49100-000 São Cristóvão - SE, Brasil

Maria da Paz F. do Nascimento

Departamento de Química, Universidade Federal de São Carlos, 13565-905 São Carlos - SP, Brasil

Recebido em 1/8/07; aceito em 30/4/08; publicado na web em 26/9/08

\begin{abstract}
Essential oil was extracted from leaves of Hyptis pectinata using hydrodistillation, and its composition determined using GC-FID and GC-MS. Chemical analysis showed that there was a predominance of sesquiterpenes, of which $\beta$-caryophyllene (18.34\%), caryophyllene oxide $(18.00 \%)$ and calamusenone $(24.68 \%)$ were measured for the first time in the genus Hyptis. Twenty-one compounds were identified, and calamusenone was isolated using preparative thin layer chromatography with a silica gel plate (60 $\mathrm{PF}_{254}$ ). The minimal inhibitory concentration (MIC) and minimal microbicidal concentration (MMC) were determined for various pathogenic microorganisms. H. pectinata oil was most effective against Gram (+) bacteria and yeasts.
\end{abstract}

Keywords: Hyptis pectinata; antimicrobial activity; essential oil.

\section{INTRODUCTION}

Essential oils from aromatic plant species are used in industry for the production of soaps, perfumes and toiletries. Many have been used in developing countries as alternative treatments for various health problems. ${ }^{1}$

The Hyptis genus of the Lamiaceae family includes around 400 species distributed throughout the Americas, West Africa, Fiji Island (Oceania), and western India. They are found in northern Brazil. The members of this genus have high economic importance because they are a source of aromatic essential oil, and are also used for landscape gardening and culinary purposes. ${ }^{2}$ However, ethno-pharmacological features and chemical compositions have only been studied for 25 species. $^{2,3}$

Hyptis pectinata (L.) Poit., popularly known in Brazil as "sambacaitá" or "canudinho", is an herbaceous plant with aromatic leaves, and small bilabial flowers, ${ }^{4}$ used extensively in traditional medicine by local populations for the treatment for conditions including rhinopharyngitis, nasal congestion, skin diseases, gastric disorders, fever, and various bacterial and fungal infections. ${ }^{5} \mathrm{H}$. pectinata has also been extensively used in mouth rinses by the population of the state of Sergipe, Brazil. ${ }^{3}$

Earlier work has investigated the pharmacological properties of $H$. pectinata in the forms of essential oil, aqueous extract, methanolic extract or leaves. Bispo et al. ${ }^{4}$ and Lisboa et al. ${ }^{5}$ reported antinociceptive and antiedematogenic action of the aqueous extract,

*e-mail: ritinhat@hotmail.com with low toxicity. Mélo et al. ${ }^{6}$ identified a promoter effect on liver regeneration following partial hepatectomy. Although there have been a limited number of investigations of the bioactivity of $H$. pectinata, information concerning the antibacterial and antifungal properties of the essential oil is scarce. Malan ${ }^{7,8}$ reported high antifungal and antibacterial activity and, more recently, Fragoso-Serrano et al. ${ }^{9}$ noted in vitro anti-staphylococcal activity from the isolated pectinolides A, B, C and H. Oils from several Lamiaceae species have been tested for their antibacterial properties, with all species being shown to be effective in reducing growth of the bacteria tested..$^{10}$ The aim of the present work was to determine the chemical composition and evaluate the antimicrobial activity of the essential oil of $H$. pectinata, cultivated in Sergipe state, Brazil, against reference strains of Gram (+) and Gram (-) bacteria, and yeasts (Candida genus and Cryptococcus neoformans).

\section{EXPERIMENTAL}

\section{Plant material}

Cultivation of Hyptis pectinata was undertaken at the Federal University of Sergipe (UFS) Experimental Farm, São Cristóvão, Sergipe, Brazil (10 18' 20.7' (S); 36 39' 7.2” (W) and $120 \mathrm{~m}$ above sea level). Leaves were collected from plants of $H$. pectinata accession SAM0012, of the germ plasm bank at UFS. A reference specimen was deposited at the UFS herbarium (registry number 7454). Leaves were dried in an oven (at $40^{\circ} \mathrm{C}$ ) for a period of 5 days, with air renewal and circulation, until complete dehydration was achieved, then ground to a coarse powder. 


\section{Essential oil extraction}

The essential oil was obtained by hydrodistillation (for $3 \mathrm{~h}$ ) of $H$. pectinata leaves in a Clevenger-type apparatus, until no more condensing oil could be seen. The essential oil was separated from the aqueous solution (hydrolate), dried with anhydrous $\mathrm{Na}_{2} \mathrm{SO}_{4}$ (yield $0.5 \% \mathrm{v} / \mathrm{w}$ ), transferred to an amber glass flask, and kept at a temperature of $-10{ }^{\circ} \mathrm{C}$ until used.

\section{Gas chromatography - mass spectrometry (GC-MS) and gas chromatography (GC-FID)}

Oil sample analysis was performed on a Shimadzu QP5050A gas chromatograph (Shimadzu Corporation, Kyoto, Japan), interfaced to a mass spectrometer (GC-MS). The following conditions were used: DB5 column (30 cm x $0.25 \mathrm{~mm}$ i.d., $5 \%$ phenylmethylpolysiloxane); helium (99.999\%) carrier gas at a constant flow of $1.2 \mathrm{~mL} \mathrm{~min}^{-1} ; 0.5 \mu \mathrm{L}$ injection volume (in ethyl acetate); injector split ratio of $1: 20$; injector temperature $250{ }^{\circ} \mathrm{C}$; electron impact mode at $70 \mathrm{eV}$; ion-source temperature $280{ }^{\circ} \mathrm{C}$. The oven temperature was programmed from $80^{\circ} \mathrm{C}$ (isothermal for $2 \mathrm{~min}$ ), with an increase of $3{ }^{\circ} \mathrm{C} \mathrm{min}-1$ to $180{ }^{\circ} \mathrm{C}$, then $10{ }^{\circ} \mathrm{C} \mathrm{min}^{-1}$ to 300 ${ }^{\circ} \mathrm{C}$, and $10 \mathrm{~min}$ isothermal at $300^{\circ} \mathrm{C}$. Mass spectra were taken at $70 \mathrm{eV}$, with a scan interval of $0.5 \mathrm{~s}$, and considered ion fragments in the range 40 to $450 \mathrm{Da}$.

Quantitative analysis of the chemical constituents was performed using a Shimadzu GC-17A flame ionization gas chromatograph (GC-FID). A fused silica ZB5 capillary column (5\% phenyl, 95\% dimethylpolysiloxane, $30 \mathrm{~m} \times 0.25 \mathrm{~mm}$ i.d., $0.25 \mu \mathrm{m}$ film thickness) was employed (Phenomenex, Torrance, CA, USA), under the same conditions as the GC-MS procedure. Quantification of each constituent was estimated by area normalization (\%). Compound concentrations were calculated from the GC peak areas, and arranged in order of elution.

\section{Identification of essential oil constituents}

A mixture of linear hydrocarbons $\left(\mathrm{C}_{9} \mathrm{H}_{20}-\mathrm{C}_{19} \mathrm{H}_{40}\right)$ was injected under the same conditions as samples, and identification of constituents performed by comparing the spectra obtained with those of the equipment's database (NIST 21 and NIST 107), and by using the Kovats Index, calculated for each constituent as previously described. ${ }^{11}$

Isolation and characterization of calamusenone $(2,3,4,5,7,8$ hexahydro-1.4-dimethyl-7-(1-methylethylidene)-6(1H)azulenone)

The oil was diluted in $1.0 \mathrm{~mL}$ of ethyl acetate and applied to a preparative thin layer chromatography plate $(10 \times 20 \mathrm{~cm})$ coated with $2 \mathrm{~mm}$ of silica gel $\left(60 \mathrm{PF}_{254}\right)$. The plate was eluted twice with hexane, followed by elution with hexane/ethyl acetate (95:5). After elution, the plate was observed using ultraviolet light (Vilber Lourmat) at a wavelength of $254 \mathrm{~nm}$ and $\mathrm{Rf}$ range of 0.41 to 0.54 . The plate was extracted using ethyl acetate, the extract filtered, and the solvent removed using a rotary evaporator operated at $40{ }^{\circ} \mathrm{C}$. The residue contained the calamusenone (34 mg, 34\%). NMR spectra, obtained using a Bruker instrument, and characterized by ${ }^{1} \mathrm{H} \mathrm{NMR}\left(\mathrm{CDCl}_{3}\right.$, $400 \mathrm{MHz})$ and ${ }^{13} \mathrm{C} \mathrm{NMR}\left(\mathrm{CDCl}_{3}, 100 \mathrm{MHz}\right)$, were consistent with previously reported data for calamusenone ${ }^{12}$ (Figure 1). The EI-MS mass spectrum of calamusenone contains: $\mathrm{m} / \mathrm{z} 218\left(\mathrm{M}^{+}, 100 \%\right), \mathrm{m} / \mathrm{z}$ 203 (24\%), m/z 175 (31\%), m/z. 161 (51\%), m/z 133 (53\%), m/z 105 (76\%), $m / z, 83(49 \%)$ and $m / z, 41(66 \%)$.

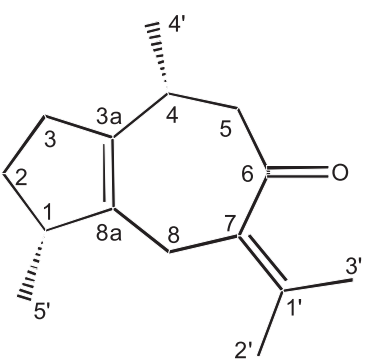

Figure 1. Structural formula of the guaiane-type sesquiterpene derivative 2,3,4,5,7,8-hexahydro-1,4-dimethyl-7-(1-methylethylidene)-6(1H)-azulenone (calamusenone), the dominant compound identified in the essential oil of $H$. pectinata

\section{Antimicrobial activity}

The microorganisms tested were the yeasts Candida albicans (ATCC 1884), Candida guilhermondii (ATCC 6260), Candida dubliniensis (MYA-646), Candida parapsilosis (ATCC 22019), Cryptococcus neoformans (IOC 7523), and the bacteria Citrobacter freundii (ATCC 8090), Salmonella enteritidis (ATCC 25928), Bacillus subtilis (ATCC 6633), Escherichia coli (ATCC 1284), Pseudomonas aeruginosa (ATCC 1238), Serratia marcescens (ATCC 13880), Klebsiella pneumoniae (ATCC 13883), Enterobacter cloacae (ATCC 13640), Enterococcus faecalis (ATCC 29212), Staphylococcus aureus (ATCC 12600) and Staphylococcus epidermidis (ATCC 12228).

\section{Minimal inhibitory concentration (MIC) and minimal microbicidal concentration (MMC) assays}

Inhibition of microorganism growth was determined using a micro dilution assay in a sterile 96 -well micro titre plate. ${ }^{13,14} \mathrm{H}$. pectinata essential oil was tested at concentrations ranging from 0.5 to 300 $\mathrm{mg} \mathrm{mL}^{-1}$ (diluted in $0.5 \%$ DMSO according to CLSI M7-A6 ${ }^{15}$ and $\left.\mathrm{M} 27-\mathrm{A} 2^{16}\right)$.

Each well contained $100 \mu \mathrm{L}$ of twofold serially diluted essential oil, $95 \mu \mathrm{L}$ of double strength BHI growth medium (bacteria) or RPMI 1640 (yeasts), and $0.5 \mu \mathrm{L}$ of an overnight culture of each strain, representing, approximately, $5 \times 10^{4}$ bacterial cells $\mathrm{mL}^{-1}$ and $2.5 \mathrm{x}$ $10^{3}$ yeast cells $\mathrm{mL}^{-1}$.

The controls comprised pure growth medium, or inoculated growth medium, without the test agent. The plates were incubated at $37^{\circ} \mathrm{C}$ for $24 \mathrm{~h}$ (bacteria) or $37^{\circ} \mathrm{C}$ for $48 \mathrm{~h}$ (yeasts), except Cryptococcus neoformans, which was incubated for $72 \mathrm{~h}$. The results were based on visible growth or inhibition. The plate was shaken for 30 $\mathrm{s}$ before each reading.

The MIC was defined as the minimum concentration of the test agent which caused $>80 \%$ growth inhibition, compared to untreated cultures.

\section{Minimal bactericidal concentration (MBC) and minimal fungicidal concentration (MFC)}

To assess whether the action of the essential oil was microbiostatic or microbicidal, $100 \mu \mathrm{L}$ of the microbial culture were taken from concentrations equal to, or higher than, the MIC, streaked on $\mathrm{BHI}$ or Sabouraud agar plates, and incubated at $37{ }^{\circ} \mathrm{C}$ for $48 \mathrm{~h}$ (except Cryptococcus neoformans, which was incubated for $72 \mathrm{~h}$ ). No growth at concentrations higher than, or equal to, the MIC indicated microbicidal action. Control tests were run simultaneously by adding solvents without the essential oil. All experiments were undertaken in duplicate, and average values were calculated. 


\section{RESULTS AND DISCUSSION}

The composition and relative percentages of compounds in the essential oil were determined (Table 1). Twenty-one compounds were found. Twenty $(98.85 \%)$ were identified as sesquiterpenoids, with high contents of calamusenone $(24.64 \%), \beta$-caryophyllene $(18.34 \%)$ and caryophyllene oxide (18\%). However, the chemical composition of $H$. pectinata essential oil is variable, and some authors have reported different results. Malan et al. ${ }^{8}$ investigated the chemical composition of $H$. pectinata from West Africa, and found that thymol and $p$-cymene were the major components. Tchoumbougnang et al. ${ }^{17}$ identified germacrene D and $\beta$-caryophyllene as the major constituents. Pietschmann et al. ${ }^{18}$ compared three $H$. pectinata oils from different origins, and found that the major components were sabinene and caryophyllene (Indian oil), $p$-cymene (West African oil), and $\beta$-caryophyllene followed by $\beta$-elemene (Fiji island oil). These differences may be due to intra-species genetic variation, or to other factors including management style, climate, soil type, season, type of material (fresh or dry), extraction technique or geographical location (latitude and altitude). ${ }^{19-22}$

The high sesquiterpene content of Hyptis pectinata essential oil from Sergipe, particularly the high percentage of $\beta$-caryophyllene, is a common feature of essential oils. ${ }^{14,17,18}$ Almeida et al ${ }^{23}$ highlight many studies which report on the antimicrobial properties of essential oils containing a significant sesquiterpene fraction. Essential oils rich in sesquiterpenes present biological properties which include spasmolytic, ${ }^{24}$ local anaesthetic, ${ }^{25}$ anti-inflammatory ${ }^{26}$ antimicrobial ${ }^{23}$ and antifungal action. ${ }^{27}$

Calamusenone, the major component found here, is frequently isolated from Acorus calamus, ${ }^{17,28}$ a semi-aquatic plant of the Araceae family found in central Asia, India, North America and Europe. This compound is not well researched, and there exist few data in the literature concerning its biological activity. According to $\mathrm{Hu}$ and Feng, ${ }^{29}$ Acorus calamus is used in "Chang-Pu" traditional Chinese medicine for treatment of dementia. The herbal medicine product includes the roots of three major Acorus species (A. calamus L., A. gramineus Soland and A. tatarinowii Schott). Calamusenone has recently been isolated from A. tatarinowii. ${ }^{29}$

Since this compound had not yet been previously isolated from plants of the Hyptis genus, and because there is a large genetic distinction between Acorus and Hyptis, we performed its isolation, and identification using NMR and retention index, and compared our findings with those reported for A. calamus. ${ }^{28,30}$

The ${ }^{1} \mathrm{H}$ NMR $400 \mathrm{MHz}$ spectra revealed $\delta 98(1 \mathrm{H}, 17 \mathrm{~Hz}), \delta$ $2.72(2 \mathrm{H}, 17 \mathrm{~Hz}), \delta 1.06(3 \mathrm{H}, 7 \mathrm{~Hz})$ and $\delta 1.05(3 \mathrm{H}, 7 \mathrm{~Hz})$, with 5 multiplets, $\delta 1.5(1 \mathrm{H}), \delta 2.2(2 \mathrm{H}), \delta 2.47(1 \mathrm{H}), \delta 2.60(1 \mathrm{H})$ and $\delta$ $2.69(1 \mathrm{H})$ (Table 3$)$. The ${ }^{13} \mathrm{C}$ NMR spectral analysis indicated the existence of 15 carbon atoms. Of these, four were not hydrogenates (C), two were mono-hydrogenates $(\mathrm{CH})$, four were di-hydrogenates $\left(\mathrm{CH}_{2}\right)$, four were tri-hydrogenates $\left(\mathrm{CH}_{3}\right)$, and one was carbonylic carbon (CO). Table 2 indicates the similarity between the present data and those reported in the literature for calamusenone isolated from A. calamus.

Many authors have demonstrated the antimicrobial activity of essential oils. Oliveira et al. ${ }^{31}$ showed that Lippia origanoides essential oil was effective against Candida spp., S. aureus, S. mutans, and other microorganisms. Nascimento et al. ${ }^{3}$ demonstrated the antiStreptococcus mutans activity of $H$. pectinata, using its essential oil rich in caryophyllene oxide (28\%) and caryophyllene (28.3\%).

Some studies have concluded that whole essential oils possess greater antibacterial activity than the mixed major components, ${ }^{32,33}$ which suggests that the minor components might be critical to such activity, due to synergistic (or other) effects.

In the present study, the antimicrobial and microbicidal potentials of $H$. pectinata essential oil (Table 3) were tested using Gram (+) and Gram (-) bacteria, and standard strains of yeast from the ATCC (American Typing Culture Collection) and IOC (Instituto Oswaldo Cruz, Rio de Janeiro) collections. Negative MIC values were obtained for the yeasts and the Gram (+) bacteria. The most sensitive yeasts were C. albicans $\left(\mathrm{MIC}=0.58 \mathrm{mg} \mathrm{mL}^{-1}\right), C$. neoformans $(\mathrm{MIC}$

Table 1. Chemical compounds present in Hyptis pectinata essential oil

\begin{tabular}{|c|c|c|c|c|c|}
\hline Peak & RT (min) & Compound & $(\%)$ & RRI exp. ${ }^{a}$ & RRI lit. ${ }^{b}$ \\
\hline 1 & 4.050 & $\alpha$-Pinene & 1.39 & 937 & 939 \\
\hline 2 & 4.700 & 1-Octen-3-ol & 2.23 & 975 & 979 \\
\hline 3 & 4.817 & $\beta$-Pinene & 6.95 & 982 & 980 \\
\hline 4 & 5.867 & Limonene & 2.06 & 1030 & 1031 \\
\hline 5 & 7.550 & Linalool & 1.54 & 1099 & 1098 \\
\hline 6 & 16.375 & $\alpha$-Copaene & 2.40 & 1381 & 1376 \\
\hline 7 & 16.867 & $\beta$-Elemene & 2.15 & 1396 & 1391 \\
\hline 8 & 17.800 & $\beta$-Caryophyllene & 18.34 & 1425 & 1419 \\
\hline 9 & 18.900 & $\alpha$-Humulene & 1.50 & 1459 & 1455 \\
\hline 10 & 19.758 & Germacrene-D & 3.07 & 1486 & 1485 \\
\hline 11 & 20.050 & cis- $\beta$-Guaiane & 3.76 & 1495 & 1493 \\
\hline 12 & 20.258 & Bicyclogermacrene & 1.49 & 1502 & 1500 \\
\hline 13 & 20.525 & $\beta$-Bisabolene & 1.17 & 1510 & 1506 \\
\hline 14 & 20.758 & $\gamma$-Cadinene & 1.75 & 1518 & 1514 \\
\hline 15 & 21.025 & trans-Calamene & 2.40 & 1527 & 1529 \\
\hline 16 & 21.958 & epi-Longipenol & 1.07 & 1558 & 1564 \\
\hline 17 & 22.708 & Globulol & 1.24 & 1583 & 1583 \\
\hline 18 & 22.892 & Caryophyllene oxide & 18.00 & 1589 & 1583 \\
\hline 19 & 23.833 & 1,10-di-epi-Cubenol & 1.66 & 1621 & 1619 \\
\hline 20 & 25.767 & Calamusenone & 24.68 & 1677 & $1680^{c}$ \\
\hline
\end{tabular}

${ }^{\mathrm{a}} \mathrm{RRI}=$ relative retention index using the Van den Dool equation. ${ }^{40}{ }^{\mathrm{b}}$ According to ref. $11^{\mathrm{c}}$ From ref. 30 
Table 2. ${ }^{1} \mathrm{H}$ NMR and ${ }^{13} \mathrm{C}$ NMR spectral data: A parallel between calamusenone isolated from Acorus calamus ${ }^{\mathrm{a}}$ and the sesquiterpene isolated from $H$. pectinata (access SAM003) essential oil. Chemical shifts (relative to TMS) in ( $\delta$ ) ppm, coupling constants in Hz (in parentheses), samples diluted in $\mathrm{CDCl}_{3}$

\begin{tabular}{|c|c|c|c|c|}
\hline \multirow{2}{*}{ Carbon } & \multicolumn{2}{|c|}{${ }^{1} H N M R$} & \multicolumn{2}{|c|}{${ }^{13} C N M R$} \\
\hline & A. calamus & H. pectinata & A. calamus & H. pectinata \\
\hline 1 & $2.42(1 \mathrm{H}, m)$ & $2.47(1 \mathrm{H}, m)$ & 45.052 & 44.832 \\
\hline 2 & $2.04(2 \mathrm{H}, m)$ & $2.02(2 \mathrm{H}, m)$ & 31.048 & 30.804 \\
\hline \multirow[t]{2}{*}{3} & $1.38(1 \mathrm{H}, m)$ & $1.35(1 \mathrm{H}, m)$ & 34.266 & 34.081 \\
\hline & $2.54(1 \mathrm{H}, m)$ & $2.60(1 \mathrm{H}, m)$ & & \\
\hline $3 a$ & & & 138.789 & 138.797 \\
\hline 4 & $2.68(1 \mathrm{H}, m)$ & $2.69(1 \mathrm{H}, m)$ & 33.372 & 33.169 \\
\hline 5 & $2.77(2 \mathrm{H}, d, 6 \mathrm{~Hz})$ & $2.72(2 \mathrm{H}, d, 6 \mathrm{~Hz})$ & 48.926 & 48.736 \\
\hline 6 & & & 204.640 & 205.343 \\
\hline 7 & & & 134.474 & 134.537 \\
\hline \multirow[t]{2}{*}{8} & $2.95(1 \mathrm{H}, d, 17 \mathrm{~Hz})$ & $2.98(1 \mathrm{H}, d, 17 \mathrm{~Hz})$ & 27.353 & 27.110 \\
\hline & $3.17(1 \mathrm{H}, d, 17 \mathrm{~Hz})$ & $3.09(1 \mathrm{H}, d, 17 \mathrm{~Hz})$ & & \\
\hline $8 \mathrm{a}$ & & & 137.617 & 137.679 \\
\hline $1^{\prime}$ & & & 140.402 & 140.817 \\
\hline $2^{\prime}$ & $1.85(3 \mathrm{H}, s)$ & $1.82(3 \mathrm{H}, s)$ & 22.546 & 22.496 \\
\hline $3^{\prime}$ & $2.04(3 \mathrm{H}, s)$ & $2.03(3 \mathrm{H}, s)$ & 23.003 & 23.921 \\
\hline $4^{\prime}$ & $1.08(3 \mathrm{H}, d, 7 \mathrm{~Hz})$ & $1.06(3 \mathrm{H}, d, 7 \mathrm{~Hz})$ & 19.844 & 19.706 \\
\hline $5^{\prime}$ & $1.07(3 \mathrm{H}, d, 7 \mathrm{~Hz})$ & $1.05(3 \mathrm{H}, d, 7 \mathrm{~Hz})$ & 19.733 & 19.597 \\
\hline
\end{tabular}

Ref. 12

Table 3. Minimal inhibitory concentrations (MIC), minimal fungicidal concentrations (MFC), and minimal bactericidal concentrations (MBC) of $H$. pectinata essential oil

\begin{tabular}{|c|c|c|c|}
\hline Microorganisms & Gram +/- & $\mathrm{MIC}\left(\mathrm{mg} \mathrm{mL}^{-1}\right)$ & $\mathrm{MFC}$ and $\mathrm{MBC}\left(\mathrm{mg} \mathrm{mL}^{-1}\right)$ \\
\hline Citrobacter freundii ATCC 8090 & G- & - & - \\
\hline Salmonella enteritidis ATCC 25928 & G- & 300 & 300 \\
\hline Escherichia coli ATCC 1284 & G- & - & - \\
\hline Pseudomonas aeruginosa ATCC 1238 & G- & 200 & 200 \\
\hline Serratia marcescens ATCC13880 & G- & - & - \\
\hline Klebsiella pneumoniae ATCC 13883 & G- & 200 & 200 \\
\hline Enterobacter cloacae ATCC 13640 & G- & - & - \\
\hline Enterococcus faecalis ATCC 29212 & $\mathrm{G}+$ & 50 & 100 \\
\hline Bacillus subtilis ATCC 6633 & $\mathrm{G}+$ & 12.5 & 12.5 \\
\hline Staphylococcus aureus ATCC 12600 & $\mathrm{G}+$ & 12.5 & 100 \\
\hline Staphylococcus epidermidis ATCC 12228 & $\mathrm{G}+$ & 18.75 & 18.75 \\
\hline Neisseria gonorrhoeae ATCC 1942 & G- & 75 & 75 \\
\hline Candida albicans ATCC 18804 & & 0.58 & 0.58 \\
\hline Candida guilhermondii ATCC 6260 & & 12.5 & 25 \\
\hline Candida parapsilosis ATCC 22019 & & 25 & - \\
\hline Candida dubliniensis ATCC MYA-646 & & 3.12 & 3.12 \\
\hline Cryptococcus neoformans IOC 7523 & & 1.17 & 1.17 \\
\hline
\end{tabular}

$\left.=1.17 \mathrm{mg} \mathrm{mL}^{-1}\right)$ and $C$. dubliniensis $\left(\mathrm{MIC}=3.12 \mathrm{mg} \mathrm{mL}^{-1}\right)$. For the Gram (+) bacteria (S. aureus, S. epidermidis, B. subtilis and E. faecalis) tested in this work, the essential oil presented MIC values between 12.5 and $50 \mathrm{mg} \mathrm{mL}^{-1}$. S. aureus and B. subtilis presented the smallest MICs $\left(12.5 \mathrm{mg} \mathrm{mL}^{-1}\right)$, and E. faecalis the largest MIC (50 $\mathrm{mg} \mathrm{mL}^{-1}$ ). The activity of $H$. pectinata essential oil against fungi and Gram (+) bacteria is in agreement with the findings of Almeida et al..$^{23}$ Celiktas et al..$^{34}$ obtained MIC values of 10 and $20 \mathrm{mg} \mathrm{mL}^{-1}$, respectively, for the Gram (+) bacteria $S$. aureus and $S$ epidermidis, using Rosmarinus officinalis essential oil. Pereda-Miranda et al. ${ }^{35}$ obtained MIC values of 6.25 and $12.5 \mu \mathrm{g} \mathrm{mL}^{-1}$ for the same bacteria, using the isolated pectinolides A and $\mathrm{C}$ (compounds present in $H$. pectinata essential oil).

The oil was effective against the Gram (-) bacteria Klebsiella pneumoniae, Pseudomonas aeruginosa and Salmonella enteritidis. MIC values were 200, 200 and $300 \mathrm{mg} \mathrm{mL}^{-1}$, respectively. These are considered high, and were similar to the MBC. According to Mann et al. ${ }^{36}$ Gram (-) bacteria may be less sensitive to essential oils due to their hydrophilic external layer, which restricts access of the hydrophobic oils.

There is a current tendency not to consider MIC values above $200 \mathrm{mg} \mathrm{mL}^{-1}$ as promising, however we disagree, for several reasons. 
Essential oil activity may be related to many other factors, such as oil volatility, water solubility, and general chemical complexity. ${ }^{37}$ Synergistic or antagonistic effects cannot be evaluated using in vitro tests. ${ }^{34,38}$ Hence, there is a clear need for further work, since natural products (such as extracts and essential oils), may, despite presenting only weak anti-pathogen performance, be used either as new drug prototypes, or in association with such products. ${ }^{39}$

MFC values were similar to MIC, except for $C$. guilhermondii (MIC $=12.5 \mathrm{mg} \mathrm{mL}^{-1}, \mathrm{MFC}=25 \mathrm{mg} \mathrm{mL}^{-1}$ ). These results may be indicative of the possibility of either a fungistatic or a fungicidal dose. The oil showed a MIC of $25 \mathrm{mg} \mathrm{mL}^{-1}$ against $C$. parapsilosis, however no concentration was able to kill this organism. We can conclude that $H$. pectinata essential oil is purely fungistatic with respect to this species.

\section{CONCLUSIONS}

Chemical analysis of $H$. pectinata essential oil showed that sesquiterpenes were the main compounds present, followed by monoterpenes. Of the sesquiterpenes, calamusenone was the major component. Other sesquiterpenes, such as caryophyllene and caryophyllene oxide, were also present at significant percentages.

For the analytical conditions and microorganisms employed in this work, we can conclude that $H$. pectinata essential oil is more effective against yeasts and Gram (+) bacteria. It can only inhibit Gram-negatives at high concentrations. The essential oil shows microbicidal action against Gram (+) bacteria, however in the case of yeasts it can be considered either fungicidal or fungistatic, depending on dose or species. This activity can be attributed principally to the sesquiterpenes, such as $\beta$-caryophyllene and caryophyllene oxide, as well as other terpenes, which are known to possess antimicrobial properties. It is important to stress that synergistic action between different compounds is an important contributor to essential oil activity. Further work will be required to investigate the biological activity of the sesquiterpene, calamusenone.

\section{REFERENCES}

1. Cimanga, K.; Kambu, K.; Tona, L.; Apers, S.; De Bruyne, T.; Hermans, N.; Totté, J.; Pieters, L.; Vlietinck, A.; J. Ethnopharmacol. 2002, 79, 213.

2. Falcão, D. Q; Menezes, F. S., Rev. Bras. Farm. 2003, 84, 69.

3. Nascimento, P. F. C.; Alviano, W. S.; Nascimento, A. L. C.; Santos, P. O.; Arrigoni-Blank, M. de F.; Jesus, R. A. de; Azevedo, V. G.; Alviano, D. S.; Bolognese, A. M.; Trindade, R. de C.; O. Diseases, in press.

4. Bispo, M. D.; Mourão, R. H. V.; Franzotti, E. M.; Bomfim, K. B. R.; Arrigoni-Blank, M. de F.; Moreno, M. P. N.; Marchioro, M.; Antoniolli, A. R.; J. Ethnopharmacol. 2001, 76, 81.

5. Lisboa, A. C. C. D.; Mello, I. C. M.; Nunes, R. S.; Santos, M. A. dos; Antoniolli, A. R.; Marçal, R. M.; Cavalcanti, S. C. de H.; Fitotererapia 2006, 77, 439 .

6. Mélo, G. B.; Silva, R. L.; Melo, V. A.; Antoniolli, A. R.; Jordani-Souza, M. E.; Jordani, M. C.; Castro-e-Silva Júnior, O.; Phytomedicine 2005, 12,359 .

7. Malan, K.; Dussart, G.; Marion, C.; Loukou, Y.; Plant. Méd. Phytothér. 1986, 20, 323

8. Malan, K.; Marion, C. ; Blaise, A. ; Bessiere, J. M.; Planta Med. 1988, 54, 531 .
9. Fragoso-Serrano, M.; Gibbons, S.; Pereda-Miranda, R.; Planta Med. 2005, 71, 278.

10. Baydar, H.; Sagdiço, O.; Oxkan, G.; Karadogan, T.; Food Control. 2004, $15,169$.

11. Adams, R. P.; Identification of essential oil components by gas chromatography/ quadrupole mass spectroscopy, Allured Publishing Corporation: Illinois, 2001, p. 456.

12. Rohr, M.; Naegeli, P.; Daly, J.; Phytochemistry 1979, 18, 279.

13. Filoche, S. K.; Soma, K.; Sissons, C. H.; Oral Microbiol. Immunol. 2005, 20, 221.

14. Ozturk, S.; Ercisli, S.; J. Ethnopharmacol. 2006, 106, 372.

15. Clinical and Laboratory Standards Institute; Metodologia dos testes de sensibilidade a agentes antimicrobianos por diluição para bactérias de crescimento aeróbico: norma aprovada $6^{a}$ ed. $-M 7-A 6$, Pennsylvania 2005, vol. 23, n. 2.

16. Clinical and Laboratory Standards Institute; Metodologia de referência para testes de diluição em caldo para determinação da sensibilidade de leveduras à terapia antifúngica: norma aprovada segunda edição. M27-A2, Pennsylvania 2005, vol. 22, n. 15.

17. Tchoumbougnang, F.; Amvan-Zollo, P. H.; Fekam-Boyom, F.; Nyegue, M. A.; Bessière, J. M.; Menut, C.; Flavour Fragr. J. 2005, 20, 340.

18. Pietchmann, M.; Vostrowsky, O.; Bestmann, H. J.; J. Essent. Oil Res. 1998, 10, 550 .

19. Apel, M. a ; Sobral, M. H.; Rev. Bras. Farm. 2006, 16, 402.

20. Asekun, O. T.; Grienrson, D. S.; Afolayan, A.; J. Food Chem. 2006, 101, 995.

21. Gobbo-Neto, L.; Lopes, N. P.; Quim. Nova 2007, 30, 374.

22. Sefidkon, F.; Abbasi, K.; Jamzad, Z.; Ahmado, S.; Food Chem. 2007, $100,1054$.

23. Almeida, L. F. R.; Delachiave, M. E. A.; Marques, M. O. M.; Rev. Bras. Plant. Med. 2005, 5, 35.

24. Cabo, J.; Plant. Med. Phyto. 1986, 20, 213.

25. Gherlardini, C.; Il Farmaco 2001, 56, 387.

26. Martin, S.; Plant. Med, Sttutg. 1993, 59, 533.

27. Tellez, M. R.; Dayan, F. E.; Schrader, K. K.; Wedge, D. E.; Duke, S. O.; J. Agric. Food Chem. 2000, 48, 3008.

28. Mazza, G.; J. Chromatogr., A 1985, 328, 179.

29. Hu, J.; Feng, X.; Plant Med. 2000, 66, 662.

30. Venskutonis, P. R.; Dagilyte, A.; J. Essent. Oil Res. 2003, 15, 313.

31. Oliveira, D. R.; Leitão, G. G.; Bizzo, H. R.; Lopes, D.; Alviano, D. S.; Alviano, C. S.; Leitão, S. G.; Food Chem. 2007, 101, 236.

32. Gill, A. O.; Delasquis, P.; Russo, P.; Holley, R. A.; Int. J. Food Microbiol. 2002, 73, 83 .

33. Burt, S.; Int. J. Food Microbiol. 2004, 94, 223.

34. Celiktas, O. Y.; Kocabas, E. E. H.; Bedir, E.; Sukan, F. V.; Ozek, T.; Baser, K. H. C.; Food Chem. 2007, 100, 553.

35. Pereda-Miranda, R.; Hernandez, L.; Villavicencio, M. J.; Novelo, M.; Ibarra, P.; Chai, H.; Pezzuto, J. M.; J. Nat. Prod. 1993, 56, 583.

36. Mann, C. M.; Cox, S. D.; Markham, S. L.; Lett. Appl. Microbiol. 2000, 30, 294.

37. Tepe, B.; Akpulat, H. A.; Sokmen, M.; Daferera, D.; Ymrutas, O.; Aydin, E.; Polissiou, M.; Sokmen, A.; Food Chem. 2006, 97, 719.

38. Nascimento, P. F. C.; Nascimento, A. C.; Rodrigues, C. S.; Antoniolli, A. R.; Santos, P. O.; Barbosa-Júnior, A. M.; Trindade, R. C.; Farmacognosia 2006, 17, 108.

39. Pyun, M.-S.; Shin, S.; Phytomedicine 2006, 13, 394.

40. Van den Dool, H.; Kratz, P. D., J. Chromatogr. 1963, 11, 463. 